Artikel Penelitian

\title{
Hubungan Tingkat Pengetahuan Terhadap Manajemen Diri Pasien Prolanis Diabetes Mellitus Tipe 2
}

\section{Relationship Between Knowledge To Self-Management of Type 2 Diabetes Mellitus Patients}

\author{
Siti Rohimah Nurasyifa ${ }^{1}$, Vitis Vini Fera $\mathbf{R U}^{1}$, Hening Pratiwi ${ }^{{ }^{*}}$ \\ ${ }^{1}$ Jurusan Farmasi, Fakultas Ilmu-ilmu Kesehatan, Universitas Jenderal Soedirman, \\ Purwokerto \\ *E-mail: hening.pratiwi@unsoed.ac.id
}

\begin{abstract}
Abstrak
Diabetes mellitus merupakan penyakit yang ditandai dengan peningkatan kadar glukosa darah dan termasuk penyakit jangka panjang yang membutuhkan manajemen diri yang baik. Faktor pengetahuan memegang peranan yang sangat penting terhadap manajemen diri. Penelitian ini bertujuan untuk mengetahui hubungan tingkat pengetahuan terhadap manajemen diri pasien. Penelitian ini merupakan studi observasional dengan pendekatan cross sectional. Dimana tingkat Pengetahuan diukur menggunakan Diabetes Knowledge Questionnaire (DKQ-24) dan tingkat manajemen diri diukur menggunakan Diabetes Self-Management Questionnaire (DSMQ). Penelitian dilaksanakan di Puskesmas I Purwokerto Timur dan pengambilan data menggunakan teknik Accidental Sampling. Sampel yang digunakan dalam penelitian ini berjumlah 35 . Hasil penelitian menunjukkan bahwa terdapat hubungan antara pengetahuan terhadap manajemen diri $p=0,000$ dengan nilai $r=0,838$ pada pasien prolanis diabetes mellitus tipe 2 .
\end{abstract}

Kata Kunci : Pengetahuan, Manajemen diri, Diabetes Mellitus

\begin{abstract}
Diabetes mellitus is a disease characterized by blood glucose elevation and long-term illness that requires good self-management. Patient knowledge has important role to overcome self-management. This study aimed to assess relationship between patient's knowledge level and self-management. This research used observational study with cross sectional approach. Patient knowledge level was measured by Diabetes Knowledge Questionnaire (DKQ24) and self-management level was measured by Diabetes Self-Management Questionnaire (DSMQ). This study was held in East Purwokerto I Public Health Center and data sources were collected by accidental sampling technique. The sample used in this study was 35 . The result showed that there was a correlation between patient knowledge level to self-management $p=0,000, r=0,838$ in diabetes mellitus type 2 .
\end{abstract}

Keywords: Knowledge, Self-Management, Diabetes Mellitus 


\section{PENDAHULUAN}

Diabetes mellitus merupakan suatu keadaan yang ditandai dengan peningkatan kadar glukosa darah akibat terjadinya gangguan sekresi insulin, kerja insulin atau keduanya (ADA, 2020). Secara umum diabetes mellitus dibagi menjadi tipe 1 dan tipe 2 (Sukandar et al, 2013). Tipe 1 ditandai dengan kerusakan sel beta pankreas akibat faktor gangguan autoimun dan genetik, sedangkan tipe 2 timbul akibat terjadinya resistensi insulin yang disebabkan karena pola hidup yang kurang baik (PERKENI, 2015). Hasil survei IDF (2017) menunjukkan bahwa Indonesia merupakan negara yang menempati peringkat ke enam terbanyak dengan jumlah 10,3 juta jiwa, untuk prevalensi penderita diabetes mellitus didunia (IDF, 2017). Dinas Kesehatan Jawa Tengah (2017) melaporkan bahwa berdasarkan hasil rekapitulasi data dari kasus baru Penyakit Tidak Menular (PTM), diabetes mellitus merupakan penyakit kedua terbanyak setelah hipertensi dengan jumlah 119,400 kasus. Sedangkan untuk wilayah banyumas masyarakat yang mengalami penyakit diabetes mellitus pada tahun 2015 berjumlah 2.105 dan mengalami peningkatan menjadi 7950 jiwa pada tahun 2017 (DINKES Banyumas, 2017).

Manajemen diri merupakan kemampuan individu dalam mengelola kehidupan sehari-hari yang bermanfaat untuk proses pengendalian, serta mengurangi dampak penyakit yang diderita pasien (Putri et al, 2013). Keberhasilan dari program manajemen penyakit kronis tidak lepas dari kemampuan individu dalam mengakses, memahami, dan menggunakan informasi dan pelayanan kesehatan untuk membuat keputusan tentang perawatan kesehatannya yang dikenal dengan Health Literacy (Sabil et al, 2019). Menurut Riyambodo et al, (2017) menyatakan bahwa pengetahuan memiliki peranan terhadap pelaksanaan perawatan diri, karena ketika individu memiliki pengetahuan yang rendah, cenderung sulit untuk menerima dan memahami informasi yang diterima. Ketika penderita diabetes kurang memiliki pengetahuan, dapat berdampak pada praktik perawatan diri yang rendah (Kueh et al, 2015). Menurut kugbey et al. (2017) hasil menunjukkan bahwa diet pasien secara signifikan dipengaruhi oleh persepsi penyakit dan pengetahuan, sehingga dapat disimpulkan bahwa pengetahuan diabetes adalah penentu utama dari praktik perawatan diri pada pasien diabetes. Ketika manajemen diri pasien baik maka kualitas hidup pasien juga baik sehingga proses terjadinya komplikasi pada pasien diabetes mellitus dapat dihindari (Suryadi, 2017).

Pasien penyakit kronik di Indonesia saat ini dapat mengikuti Progam Pengelolaan Penyakit Kronik (Prolanis) yang merupakan salah satu layanan BPJS yang di khususkan pada pasien diabetes Mellitus tipe 2 dan hipertensi (BPJS Kesehatan, 2014). Program prolanis dilaksanakan di Fasilitas Kesehatan tingkat pertama yang terdiri dari puskesmas, klinik, rumah sakit tipe D dan praktek dokter yang bekerja sama dengan BPJS. Di Purwokerto salah satu puskesmas yang melaksanakan pelayanan prolanis yaitu Puskesmas I Purwokerto Timur. Kegiatan diawali dengan pengecekan gula darah puasa, melakukan senam pagi bersama, dilanjutkan dengan sarapan dan terakhir pemberian obat. Tujuan penelitian ini adalah untuk mengetahui adanya hubungan karakteristik dan tingkat pengetahuan terhadap manajemen diri pasien prolanis diabetes mellitus tipe 2 di Puskesmas I Purwokerto Timur.

\section{BAHAN DAN METODE}

Desain penelitian yang digunakan adalah studi observasional dengan pendekatan cross-sectional. Penelitian ini bertujuan untuk mengetahui 
hubungan tingkat pengetahuan terhadap manajemen diri pasien prolanis diabetes mellitus tipe 2 di Puskesmas I Purwokerto Timur. Tingkat Pengetahuan diukur menggunakan kuesioner Diabetes Knowledge Questionnaire (DKQ-24) dan tingkat manajemen diri diukur menggunakan kuesioner Diabetes Self-Management Questionnaire (DSMQ). Teknik pengambilan sampel pada penelitian ini menggunakan teknik accidental sampling. Populasi yang digunakan pada penelitian ini berjumlah 52 responden. Untuk mengetahui jumlah sampel yang dibutuhkan, maka digunakan rumus slovin.

$$
\begin{gathered}
n=\frac{\mathrm{N}}{\mathrm{N}(\mathrm{d})^{2}+1} \\
n=\frac{52}{52(0,1)^{2}+1}=34,2 \simeq 35
\end{gathered}
$$

Keterangan :

$\mathrm{n}=$ Sampel

$\mathrm{N}=$ Populasi $=52$ pasien

$\mathrm{d}=$ Nilai presisi $90 \%$ atau $p=0,1$

Sampel yang dibutuhkan dalam penelitian ini berjumlah 35 pasien. Dimana sampel yang digunakan harus memenuhi kriteria inklusi dan eksklusi.

Kuesioner DKQ-24 mengukur pengetahuan memiliki 24 item dalam bentuk pernyataan dengan 4 domain yaitu pernyataan tentang pengetahuan umum diabetes mellitus, jenis dan penyebab diabetes, komplikasi serta hiperglikemik dan hipoglikemik. Penilaian dalam kuesioner ini di bagi menjadi 3 pilihan. Dimana ketika jawaban benar diberikan (skor 1), ketika jawaban salah diberikan (skor 0) dan jawaban tidak tahu diberi (skor 0). Pelaksanaan validitas dan reliabilitas dilaksanakan terlebih dahulu oleh peneliti kepada 30 responden di Puskesmas II Purwokerto Timur. Kuesioner pengetahuan disajikan berdasarkan skor rata-rata dan kategori tingkat pengetahuan, yaitu:

Skor rata-rata seluruh responden $=$

$$
\frac{\text { Jumlah Skor Total Seluruh Responden }}{\text { Jumlah Responden }}
$$

Hasil pengetahuan pasien prolanis diabetes mellitus dikategorikan menjadi pengetahuan tinggi, sedang dan pengetahuan rendah (tabel 1).

Tabel 1. Kategori Tingkat Pengetahuan (Garcia et al, 2001)

\begin{tabular}{ll}
\hline Total Skor & Status Pengetahuan \\
\hline $0-8$ & Rendah \\
$9-16$ & Sedang \\
$17-24$ & Tinggi \\
\hline
\end{tabular}

Instrumen manajemen diri yang digunakan dalam penelitian ini, yaitu kuesioner DSMQ (Diabetes self-management questionnaire) dari penelitian Schmitt et al. (2013) dengan 20 item dalam bentuk pernyataan. Kuesioner DSMQ dibagi menjadi 5 domain, meliputi manajemen kontrol glukosa pada pemantauan glukosa darah dan kepatuhan pengobatan, kontrol diet, aktivitas fisik, perawatan diri dan kontak dokter. Penilaian kuesioner dibagi menjadi empat pilihan jawaban, yaitu sangat setuju (skor 3), setuju (skor 2), ragu-ragu (skor 1) dan tidak setuju (skor 0) untuk pernyataan favorable. Sedangkan untuk pernyataan unfavorable pilihan jawaban, yaitu sangat setuju (skor 0), setuju (skor 1), ragu-ragu (skor 2) dan tidak setuju (skor 3). Kuesioner ini digunakan karena sudah teruji valid, reliabel dan andal untuk pasien diabetes 
mellitus serta sudah mendapatkan izin untuk menggunakan kuesioner tersebut dari pihak pemilik kuesioner (Schmitt et al, 2013). Pelaksanaan validitas dan reliabilitas dilaksanakan terlebih dahulu oleh peneliti kepada 30 responden di Puskesmas II Purwokerto Timur.

Kuesioner manajemen diri disajikan berdasarkan skor rata-rata dan kategori tingkat manajemen diri, yaitu:

Skor Setiap Responden $=\frac{\text { Jumlah Skor Responden }}{\text { Skor Maksimal Responden }} \times 100 \%$

Skor Rata-Rata Seluruh Responden $=$

$\frac{\text { Jumlah Skor Total Seluruh Responden }}{\text { Jumlah skor maksimal Seluruh Responden }} \times 100 \%$

Hasil manajemen diri pasien prolanis diabetes mellitus dikategorikan menjadi baik dan kurang baik.

Tabel 2. Kategori Tingkat Manajemen Diri (Schmitt et al, 2013)

\begin{tabular}{ll}
\hline Total Skor & Status Manajemen Diri \\
\hline$<56 \%$ & Kurang baik \\
$56-100 \%$ & Baik \\
\hline
\end{tabular}

Setelah itu dilakukan analisis bivariat. Analisis bivariat merupakan analisis yang dilakukan terhadap dua variabel, yaitu variabel bebas dan variabel terikat yang diduga berhubungan atau berkorelasi (Dahlan, 2011). Jika data terdistribusi normal maka menggunakan analisis statistik parametrik yaitu uji pearson correlation, tetapi jika data tidak terdistribusi normal maka menggunakan analisis statistik non parametrik yaitu analisis spearman. Uji ini menyatakan ada atau tidaknya hubungan antara kedua variabel, menunjukan seberapa besar hubungan yang terjadi serta menunjukan bagaimana arah hubungan antar kedua variabel tersebut. Dasar pengambilan keputusan pada uji bivariat yaitu jika angka $(p) \leq \alpha=0.05$ maka terdapat hubungan antara variabel bebas dan variabel terikat. Namun, jika angka $(p) \geq \alpha=0,05$ maka tidak terdapat hubungan antara variabel bebas dan variabel terikat (Sugiyono, 2018).

\section{HASIL DAN PEMBAHASAN}

Penelitian ini telah disetujui secara etik oleh KEPK UNSOED dengan nomor surat 1259/UN23.07.05.1/PP1/ 2019. Pengambilan data dilakukan saat kegiatan prolanis diabetes mellitus tipe 2 di Puskesmas 1 Purwokerto Timur. Hasil penelitian didapatkan sampel sebanyak 35 responden dan semua responden mengisi kuesioner secara keseluruhan dengan proses pengisian didampingi oleh peneliti. Data yang didapatkan berupa data karakteristik responden (usia, jenis kelamin, lama menderita diabetes dan tingkat pendidikan), skor dari kuesioner pengetahuan dan skor dari kuesioner manajemen diri.

\section{Gambaran karakteristik responden}

Pasien pada penelitian ini adalah pasien diabetes mellitus tipe 2 yang mengikuti Program Pengelolaan Penyakit Kronis (Prolanis) di Puskesmas I Purwokerto Timur. Sampel yang digunakan pada penelitian berjumlah 35 pasien. Karakteristik setiap pasien yang diamati yaitu jenis kelamin, usia, 
lama menderita diabetes dan pendidikan terakhir.

Berdasarkan tabel 3. menunjukkan bahwa di Puskesmas I Purwokerto Timur lebih banyak responden prolanis diabetes mellitus tipe 2 berjenis kelamin perempuan dibandingkan dengan responden berjenis kelamin laki-laki. Menurut Irnawati et al, (2014) perempuan lebih mampu menjalani pengobatan dan perawatan terhadap diri sendiri sehingga akan mempermudah proses penyembuhan. Harista (2015) menyatakan bahwa perempuan lebih berisiko mengalami diabetes dibandingkan dengan laki-laki, dikarenakan pasca menopause membuat distribusi lemak tubuh menjadi mudah terakumulasi, akibat proses hormonal tersebut menyebabkan wanita lebih berisiko menderita diabetes mellitus. Penyebab utama perempuan terkena diabetes tipe 2 karena terjadinya penurunan hormon estrogen terutama saat masa menopause, dimana hormon estrogen dan progesteron berfungsi untuk meningkatkan respon insulin di dalam darah, tetapi saat masa menopause terjadi, menyebabkan respon insulin menurun akibat dari hormon estrogen dan progesteron yang rendah. Hal inilah yang menyebabkan perempuan lebih beresiko terkena diabetes daripada laki-laki.

Tabel 3. Karakteristik Pasien Prolanis Diabetes Mellitus Tipe 2

\begin{tabular}{|c|c|c|c|}
\hline No & Karakteristik & $\sum$ Pasien & Presentase (\%) \\
\hline \multirow{4}{*}{1} & Jenis Kelamin & & \\
\hline & Perempuan & 22 & 63 \\
\hline & Laki-Laki & 13 & 37 \\
\hline & Total & 35 & 100 \\
\hline \multirow{5}{*}{2} & Usia & & \\
\hline & $<60$ tahun & 10 & 28 \\
\hline & $60-65$ tahun & 9 & 26 \\
\hline & $>65$ tahun & 16 & 46 \\
\hline & Total & 35 & 100 \\
\hline \multirow{5}{*}{3} & Tingkat Pendidikan & & \\
\hline & Rendah (Tidak Sekolah, SD, SMP) & 17 & 49 \\
\hline & Menengah (SMA) & 12 & 34 \\
\hline & Tinggi (S1/D3) & 6 & 17 \\
\hline & Total & 35 & 100 \\
\hline \multirow{5}{*}{4} & Lama Menderita Diabetes & & \\
\hline & $<3$ tahun & 3 & 8,6 \\
\hline & 3-5Tahun & 12 & 34,3 \\
\hline & $>5$ tahun & 20 & 57,1 \\
\hline & Total & 35 & 100 \\
\hline
\end{tabular}

Hasil penelitian menunjukan usia responden lebih dari 65 tahun mendapatkan jumlah paling banyak yaitu 16 pasien. Pernyataan tersebut sesuai dengan hasil Riskesdas (2013) yang menunjukkan bahwa semakin tua usia maka semakin tinggi risiko untuk menderita diabetes mellitus. Yusra (2011) memberikan asumsi bahwa semakin bertambah usia seseorang maka akan terjadi penurunan atau perubahan dari segi fisik, intelektual dan psikologis. Kemudian terjadi perubahan tingkah laku kognitif pada individu seperti kemampuan mengingat dan berfikir dalam memecahkan suatu masalah, terjadinya penurunan aktivitas untuk bergerak sehingga lebih beresiko mengalami penyakit diabetes melitus (diabetes mellitus) (Pangemanan et al, 2014).

Semakin tinggi pendidikan seseorang maka semakin tinggi juga kemampuannya menyerap informasi tentang kesehatan dan meningkatkan pencegahan dari diabetes serta meningkatkan daya deteksi terhadap kejadian 
diabetes (Cai et al, 2011). Semakin meningkat tingkat pendidikan seseorang, maka dapat meningkatkan kesadaran diri untuk hidup sehat dengan pola makan yang baik (Notoadmodjo, 2011). Pasien diabetes mellitus tipe 2 dengan tingkat pendidikan yang rendah sangat membutuhkan informasi melalui pendidikan kesehatan oleh tenaga kesehatan setempat, untuk meningkatkan pengetahuan dan kesadaran melakukan perawatan diri (Ariani, 2011).

Berdasarkan hasil penelitian, pasien yang mengalami diabetes mellitus lebih dari 5 tahun mencapai jumlah paling banyak yaitu 20 pasien $(57,5 \%)$. Hasil penelitian Emilia (2015) menyatakan bahwa semakin lama menderita diabetes mellitus maka perawatan diri diabetes akan semakin meningkat. Lama menderita diabetes mellitus erat kaitannya dengan peningkatan stress, akan tetapi jika orang tersebut mampu mengendalikan diri dalam penyakitnya, maka tingkat stres terkait diabetes tidak akan tinggi (Hikmah, 2015). Seseorang yang menderita diabetes dengan durasi lebih lama dapat beradaptasi dengan lingkungan, jika mampu mengatur distress emosional dan dapat memberikan suatu perlindungan diri terhadap stres terkait diabetes (Restada, 2016).

\section{Pengetahuan Pasien Prolanis Diabetes Mellitus Tipe 2 di Puskesmas 1 Purwokerto Timur}

Kuesioner pengetahuan dari penelitian Garcia et al., (2001) yang digunakan bertujuan untuk mengetahui tingkat pengetahuan pasien prolanis diabetes mellitus tipe 2 di Puskesmas I Purwokerto Timur. Pengetahuan pasien terkait diabetes mellitus merupakan sarana yang penting untuk membantu menangani pasien diabetes itu sendiri, sehingga semakin banyak dan semakin baik pengetahuan tentang diabetes, maka semakin baik pula dalam menangani diet diabetes mellitus (Gharaibeh et al, 2018).

Hasil skor rata-rata tingkat pengetahuan pada responden diabetes mellitus tipe 2 di Puskesmas 1 Purwokerto Timur didapatkan nilai 13,86. Dimana skor tersebut termasuk skor kategori tingkat pengetahuan sedang (9-16). Notoatmodjo (2011) mengatakan bahwa pengetahuan merupakan domain yang sangat penting untuk terbentuknya perilaku seseorang, sebab perilaku yang didasari dengan pengetahuan akan lebih dipahami daripada perilaku yang tidak didasari dengan pengetahuan. Pengetahuan pasien terkait penyakit Diabetes Melitus menjadi sangat penting, mengingat tidak sedikit pasien Diabetes Melitus yang kurang memiliki pemahaman tentang penyakit yang diderita. Akibat dari ketidakpahaman tersebut, banyak pasien menjadi tidak patuh terhadap pengobatan dan pengetahuan yang bertujuan untuk membentuk perilaku kepatuhan dalam menjalani penatalaksanaan terapi (Saifunurmazah, 2013). 
Tabel 4. Frekuensi Pengetahuan Responden Per Item

\begin{tabular}{|c|c|c|c|c|}
\hline No & Item Pernyataan & $\begin{array}{c}\sum \text { responden } \\
\text { yang menjawab } \\
\text { dengan benar } \mathrm{n} \\
(\%)\end{array}$ & $\begin{array}{c}\sum \text { responden } \\
\text { yang menjawab } \\
\text { dengan salah } \mathrm{n} \\
(\%)\end{array}$ & $\begin{array}{l}\text { Skor Rata- } \\
\text { Rata Per Item }\end{array}$ \\
\hline \multicolumn{5}{|c|}{ Domain Pengetahuan Umum Tentang Diabetes Mellitus } \\
\hline 4 & Ginjal tidak Memproduksi Insulin. ${ }^{*}$ & $7(20)$ & $28(80)$ & 0,2 \\
\hline 10 & $\begin{array}{l}\text { Olahraga Teratur Tidak akan meningkatkan kebutuhan } \\
\text { insulin atau obat diabetes lainnya. * }\end{array}$ & $16(45,7)$ & $19(54,3)$ & 0,45 \\
\hline 12 & $\begin{array}{l}\text { Insulin bekerja bukan disebabkan karena makan terlalu } \\
\text { banyak. * }\end{array}$ & $10(28,6)$ & $25(71,4)$ & 0,29 \\
\hline 6 & $\begin{array}{l}\text { Jika saya menderita diabetes, anak-anak saya memiliki } \\
\text { peluang yang lebih tinggi untuk terkena diabetes. }\end{array}$ & $26(74,3)$ & $9(25,7)$ & 0,74 \\
\hline 7 & Diabetes tidak dapat disembuhkan. * & $17(48,6)$ & $18(51,4)$ & 0,48 \\
\hline 9 & $\begin{array}{l}\text { Menguji air kencing bukan cara terbaik untuk memeriksa } \\
\text { kondisi diabetes * }\end{array}$ & $18(51,4)$ & $17(48,4)$ & 0,51 \\
\hline 15 & $\begin{array}{l}\text { Luka dan lecet pada penderita diabetes membutuhkan } \\
\text { waktu yang lebih lama untuk sembuh }\end{array}$ & $30(85,7)$ & $5(14,3)$ & 0,86 \\
\hline 16 & $\begin{array}{l}\text { Penderita diabetes harus berhati-hati saat memotong kuku } \\
\text { kaki atau tangan }\end{array}$ & $32(91,4)$ & $3(8,6)$ & 0,91 \\
\hline 17 & $\begin{array}{l}\text { Penderita diabetes tidak harus membersihkan luka dengan } \\
\text { betadine dan alkohol. * }\end{array}$ & $9(25,7)$ & $26(74,3)$ & 0,26 \\
\hline 13 & $\begin{array}{l}\text { Obat tidak lebih penting daripada diet dan olahraga untuk } \\
\text { mengendalikan diabetes. * }\end{array}$ & $20(57,1)$ & $15(42,9)$ & 0,57 \\
\hline 18 & $\begin{array}{l}\text { Cara memasak makanan sama pentingnya dengan jenis } \\
\text { makanan yang dimakan oleh penderita diabetes. }\end{array}$ & $28(80)$ & $7(20)$ & 0,8 \\
\hline 24 & Diet diabetes sebagian besar terdiri dari makanan khusus. & $26(74,3)$ & $9(25,7)$ & 0,74 \\
\hline \multicolumn{4}{|c|}{ Skor Rata-Rata Domain Pengetahuan Umum Tentang Diabetes Mellitus } & $56 \%$ \\
\hline \multicolumn{5}{|c|}{ Domain Komplikasi Diabetes Mellitus } \\
\hline 14 & Diabetes sering menyebabkan peredaran darah tidak baik & $25(71,4)$ & $10(28,6)$ & 0,71 \\
\hline 19 & Diabetes dapat merusak ginjal. & $30(85,7)$ & $5(14,3)$ & 0,86 \\
\hline 20 & $\begin{array}{l}\text { Diabetes dapat menyebabkan mati rasa pada tangan, jari, } \\
\text { dan kaki. }\end{array}$ & $29(82,8)$ & $6(17,2)$ & 0,83 \\
\hline 23 & $\begin{array}{l}\text { Stoking atau kaus kaki elastis yang ketat berdampak buruk } \\
\text { untuk penderita diabetes. }{ }^{*}\end{array}$ & $14(40)$ & $21(60)$ & 0,4 \\
\hline Skor & Rata-Rata Domain Komplikasi Diabetes Mellitus & & & $70 \%$ \\
\hline \multicolumn{5}{|c|}{ Domain Hiperglikemik dan Hipoglikemik } \\
\hline 5 & $\begin{array}{l}\text { Pada diabetes yang tidak diobati, jumlah gula dalam darah } \\
\text { biasanya meningkat. }\end{array}$ & $31(88,6)$ & $4(11,4)$ & 0,89 \\
\hline 8 & $\begin{array}{l}\text { Kadar gula darah puasa sebesar } 210 \mathrm{mg} / \mathrm{dl} \text { adalah terlalu } \\
\text { tinggi. }\end{array}$ & $33(94,3)$ & $2(5,7)$ & 0,94 \\
\hline 21 & $\begin{array}{l}\text { Gemetar dan berkeringat bukan termasuk tanda-tanda gula } \\
\text { darah tinggi. * }\end{array}$ & $26(74,3)$ & $9(25,7)$ & 0,26 \\
\hline 22 & $\begin{array}{l}\text { Sering buang air kecil dan haus adalah tanda-tanda gula } \\
\text { darah rendah. * }\end{array}$ & $21(60)$ & $14(40)$ & 0,6 \\
\hline \multicolumn{2}{|r|}{$\begin{array}{l}\text { Skor Rta-Rata Domain Hiperglikemik dan Hipoglikemik } \\
\text { Jenis Penyakit dan Penyebabnya }\end{array}$} & & & $67 \%$ \\
\hline 1 & $\begin{array}{l}\text { Penyebab diabetes tidak disebabkan karena makan terlalu } \\
\text { banyak gula dan makanan manis lainnya. }{ }^{*}\end{array}$ & $6(17,2)$ & $29(82,8 \%)$ & 0,17 \\
\hline 2 & $\begin{array}{l}\text { Salah satu penyebab diabetes adalah kurangnya insulin } \\
\text { yang efektif dalam tubuh }\end{array}$ & $26(74,3)$ & $9(25,7 \%)$ & 0,74 \\
\hline 3 & $\begin{array}{l}\text { Diabetes tidak disebabkan oleh kegagalan kerja ginjal } \\
\text { dalam mencegah gula keluar dari air kencing. * }\end{array}$ & $7(20)$ & $28(80 \%)$ & 0,2 \\
\hline 11 & $\begin{array}{l}\text { Ada dua jenis penyakit diabetes: Tipe } 1 \text { (tergantung pada } \\
\text { insulin) dan Tipe } 2 \text { (tidak tergantung pada insulin). }\end{array}$ & $23(65,7)$ & $12(34,3 \%)$ & 0,66 \\
\hline \multicolumn{4}{|c|}{ Skor Rata- Rata Domain Jenis Penyakit dan Penyebabnya } & $44,3 \%$ \\
\hline
\end{tabular}

Skor rata-rata tingkat pengetahuan seluruh responden

* Pernyataan unfavorable yang diubah menjadi pernyataan favorable

* Skor maksimal kuesioner yaitu 24 
Hasil penelitian dinyatakan bahwa pasien masih kurang memiliki pengetahuan terkait jenis penyakit diabetes dan penyebabnya. Dimana pasien yang menjawab benar pada domain tersebut sebanyak 44,3\%. Pernyataan tersebut terdiri dari 4 item (item 1, 2, 3 dan 11) dimana responden yang memiliki tingkat persentase terendah untuk menjawab benar yaitu pada item 1 dan 3 terkait penyebab diabetes. Hasil penelitian dinyatakan bahwa 80\% pasien mengira bahwa diabetes mellitus disebabkan karena kegagalan kerja ginjal dalam mencegah gula keluar dari air kencing. Menurut KEMENKES (2013) Diabetes mellitus merupakan suatu penyakit yang ditandai dengan peningkatan kadar glukosa dalam darah dan terbagi menjadi diabetes tipe 1 dan tipe 2. Dimana Diabetes tipe 1 ditandai dengan kerusakan sel beta pankreas akibat faktor gangguan autoimun, sedangkan diabetes tipe 2 disebabkan karena tubuh tidak dapat menggunakan insulin yang di produksi secara efektif (resistensi insulin) disertai dengan faktor pola hidup yang kurang baik (Arisman, 2011).

Pengetahuan terkait komplikasi juga penting diketahui oleh setiap pasien Diabetes Mellitus. Kuesioner DKQ-24 juga memiliki pernyataan terkait komplikasi yang dapat terjadi pada pasien diabetes yang dituangkan pada pernyataan nomor $14,19,20$ dan 23. Sebagian besar pasien menjawab pernyataan tersebut dengan benar dan hanya $30 \%$ pasien yang menjawab pernyataan dengan salah. Sebenarnya kematian pada diabetes mellitus terjadi tidak secara langsung akibat hiperglikemik, tetapi berhubungan dengan komplikasi yang terjadi, karena kadar glukosa darah yang tidak terkendali dan tidak tertangani dengan baik bisa menyebabkan timbulnya komplikasi makrovaskuler dan mikrovaskuler. Hasil penelitian menyatakan bahwa 85,7\% pasien telah mengetahui bahwa diabetes dapat menyebabkan kerusakan pada ginjal (nefropati). Nefropati diabetik merupakan komplikasi penyakit diabetes mellitus yang termasuk dalam komplikasi mikrovaskular, yaitu komplikasi yang terjadi pada pembuluh darah halus (kecil). Hal ini disebabkan karena terjadi kerusakan pada pembuluh darah halus di ginjal yang menimbulkan kerusakan glomerulus yang berfungsi sebagai penyaring darah, tingginya kadar gula dalam darah membuat struktur ginjal berubah sehingga fungsi ginjal terganggu (Schwinghammer, 2015).

Pengetahuan umum terkait dengan penyakit diabetes dibagi menjadi 4 kelompok yaitu pengetahuan terkait insulin (item 4, 10 dan 12), penyakit diabetes $(6,7$ dan 9), penanganan luka (item 15, 16 dan 17) serta diet dan olahraga $(13,18$, dan 24). Hasil penelitian didapatkan bahwa $80 \%$ pasien menganggap benar terkait pernyataan bahwa fungsi dari ginjal yaitu memproduksi insulin. Sehingga dapat disimpulkan pasien masih belum mengetahui fungsi dari ginjal. Menurut PERKENI (2015) ginjal merupakan organ yang berfungsi memfiltrasi sekitar 163 gram glukosa sehari, dimana 90\% dari glukosa terfiltrasi ini akan diserap kembali melalui peran SGLT-2 (Sodium Glucose co-Transporter) pada bagian tubulus proksimal, sedangkan $10 \%$ sisanya akan di absorbsi melalui peran SGLT-1 pada tubulus desenden dan asenden, sehingga akhirnya tidak ada glukosa dalam urine.

Item 6, 7 dan 9 menjelaskan tentang pengetahuan terkait penyakit diabetes. Sebanyak $58,1 \%$ pasien menjawab benar untuk penyataan pada item 6 , terkait peluang tingginya terkena penyakit diabetes pada anak dari orang tua yang mengalami penyakit diabetes. Menurut Hasdiana (2012) riwayat keturunan menjadi salah satu faktor penyebab terjadinya penyakit diabetes mellitus, yang nantinya dapat diwariskan dari orangtua kepada anak. Seseorang bisa lebih cepat terkena penyakit diabetes mellitus apabila memiliki garis keturunan dari ibu yang terkena penyakit diabetes dan lebih mudah lagi bila 
memiliki riwayat garis keturunan diabetes gabungan gen pembawa sifat diabetes mellitus dari ayah dan ibu (Santosa et al, 2017).

Sebanyak 51,7\% pasien masih menjawab salah pada item 13 terkait pernyataan bahwa obat lebih penting daripada diet dan olahraga untuk mengendalikan diabetes. Menurut Waspadji (2011) upaya untuk menurunkan kadar gula darah yaitu melalui empat pilar penatalaksanaan diabetes mellitus seperti edukasi, perencanaan makan, latihan jasmani dan terapi farmakologi. Langkah pertama yang harus dilakukan adalah penatalaksanaan non farmakologis yaitu perubahan gaya hidup berupa penatalaksanaan diet dan aktivitas fisik (Sukardji, 2011). Tujuan penatalaksaan diet adalah membantu penderita diabetes dalam perbaikan gizi untuk mendapatkan kontrol metabolik yang lebih baik (Soegondo, 2011). Ketidakpatuhan pasien dalam perencanaan makan yang disarankan oleh petugas kesehatan merupakan salah satu kendala dalam keberhasilan penatalaksanaan diabetes mellitus tipe 2 (Sukardji, 2011). Meningkatnya gula darah pada pasien diabetes mellitus berperan sebagai penyebab dari ketidak seimbangan jumlah insulin, oleh karena itu diet menjadi salah satu pencegahan supaya glukosa darah tidak meningkat dan dapat membantu mengontrol gula darah (Soegondo, 2015).

Item 15,16 dan 17 merupakan pernyataan tentang penanganan luka pada pasien diabetes mellitus. Sebanyak $67,6 \%$ responden menjawab pernyataan tersebut dengan benar, terkait pernyataan bahwa luka dan lecet pada pasien diabetes membutuhkan waktu lebih lama untuk sembuh. Pasien diabetes harus berhati-hati saat memotong kuku dan harus membersihkan luka dengan betadine. Luka diabetes (diabetic ulcers) sering kali disebut diabetics foot ulcers, luka neuropati, luka diabetik (Maryunani, 2013). Luka diabetes dengan gangren didefinisikan sebagai jaringan nekrosis atau jaringan mati yang disebabkan karena adanya emboli pembuluh darah besar arteri pada bagian tubuh sehingga suplai darah terhenti (Maryunani, 2013).

Menurut Sari (2014) Hiperglikemik kronik pada diabetes mellitus berkontribusi terhadap munculnya berbagai komplikasi kerusakan jangka panjang, disfungsi dan kegagalan berbagai organ seperti mata, ginjal, saraf, jantung dan pembuluh darah. Item no 5, 8, 21 dan 22 memberikan pernyataan terkait keadaan hipoglikemik dan hiperglikemik pada pasien diabetes mellitus. Dari 4 pernyataan tersebut sebanyak $67.15 \%$ menjawab pernyataan dengan benar. Jawaban responden yang paling banyak salah tertuang pada pernyataan no 21 dan 22, dimana pasien banyak yang menjawab keliru antara gejala atau tanda-tanda terjadinya hipoglikemik dan hiperglikemik. Hiperglikemia merupakan suatu keadaan yang ditandai dengan peningkatan kadar glukosa darah tinggi (300-600 mg/dl) sedangkan hipoglikemia merupakan suatu keadaan yang ditandai dengan menurunya kadar glukosa darah $<70 \mathrm{mg} / \mathrm{dl}$.

Tabel 5. Frekuensi Tingkat Pengetahuan Responden

\begin{tabular}{ccc}
\hline Kategori Tingkat Pengetahuan & Jumlah Responden & Persentase (\%) \\
\hline Rendah (0-8) & 2 & 5,7 \\
Sedang (9-16) & 25 & 71,4 \\
Tinggi (17-24) & 8 & 22,9 \\
\hline Total & $\mathbf{3 5}$ & $\mathbf{1 0 0}$ \\
\hline
\end{tabular}


Berdasarkan hasil kategori tingkat pengetahuan pasien prolanis diabetes mellitus di Puskesmas 1 Purwokerto Timur menunjukkan bahwa kategori tingkat pengetahuan sedang paling banyak dimiliki oleh responden yaitu sebesar $71,4 \%$. Pengetahuan pasien tentang diabetes mellitus merupakan sarana yang dapat membantu pasien menjalankan penanganan diabetes, sehingga semakin banyak dan semakin baik pasien diabetes mellitus mengetahui tentang diabetes mellitus, pasien dapat mengubah perilakunya dan dapat mengendalikan kondisi penyakitnya sehingga berdampak pada kualitas hidup yang baik (Perdana et al, 2013).

\section{Manajemen Diri Pasien Prolanis Diabetes Mellitus Tipe 2 di Puskesmas I Purwokerto Timur}

Manajemen diri pasien prolanis diabetes mellitus pada penelitian Schmitt et al. (2013) dikategorikan menjadi kategori baik dan kategori kurang baik, dimana status manajemen diri dikatakan baik ketika memiliki nilai manajemen diri $>56 \%$ dan dikatakan kurang baik ketika memiliki nilai manajemen diri $<56 \%$. Hasil penelitian didapatkan bahwa skor rata-rata manajemen diri pada responden, yaitu $67,6 \%$. Skor tersebut termasuk skor kategori baik. Hal tersebut sejalan dengan penelitian Dhamayanti (2018) yang menyatakan bahwa pasien prolanis diabetes mellitus tipe 2 di Bandar lampung juga memiliki tingkat manajemen diri yang baik lebih dari 50\%. Tujuan penerapan self-management adalah untuk mencapai pengontrolan gula darah secara optimal serta mencegah terjadinya komplikasi, karena self-management memiliki peranan penting dalam meningkatkan kualitas kesehatan dan kesejahteraan pasien (Sulistria, 2013).

Kuesioner DSMQ yang digunakan pada penelitian ini dibagi menjadi 4 domain, dimana domain yang memiliki persentase terkecil terletak pada kontrol diet pasien. Dari hasil penelitian didapatkan bahwa hanya 17,6\% pasien menjawab sangat setuju dan $55,3 \%$ pasien menjawab setuju terkait kontrol diet. Menurut Suyono (2009) kontrol diet penting untuk dilakukan, karena bertujuan untuk membantu penderita diabetes mellitus tipe 2 memperbaiki kebiasaan makan sehingga nantinya dapat mengendalikan kadar glukosa, lemak dan tekanan darah. Penerapan diet merupakan salah satu komponen utama dalam keberhasilan penatalaksanaan diabetes, tetapi sering kali menjadi kendala dalam pelayanan diabetes, karena dibutuhkan kepatuhan dan motivasi dari pasien itu sendiri (Aweko et al, 2018). Pada dasarnya pasien diabetes mellitus banyak yang telah mengetahui anjuran diet tetapi banyak yang tidak mematuhinya, dikarenakan banyak yang menganggap bahwa makanan diet untuk pasien diabetes mellitus cenderung tidak menyenangkan, sehingga pasien makan sesuai dengan keinginan bila belum menunjukkan gejala serius (Setyorini, 2017). 
Tabel 6. Frekuensi Manajemen Diri Responden Per Item

\begin{tabular}{|c|c|c|c|c|c|c|}
\hline \multirow[b]{2}{*}{ No } & \multirow[b]{2}{*}{ Item Pernyataan } & \multicolumn{4}{|c|}{$\sum$ Manajemen Diri responden per item } & \multirow[b]{2}{*}{$\begin{array}{c}\text { Skor Rata- } \\
\text { rata per } \\
\text { item }\end{array}$} \\
\hline & & $\begin{array}{l}\sum \underset{n}{\text { sangat setuju }} \\
\qquad \%)\end{array}$ & $\sum$ setuju n (\%) & $\begin{array}{l}\sum \text { Ragu- } \\
\text { ragu n (\%) }\end{array}$ & $\begin{array}{l}\sum \text { Tidak } \\
\text { Setuju } \mathbf{n}(\%)\end{array}$ & \\
\hline \multicolumn{7}{|c|}{ Domain Kontrol Diet } \\
\hline 2 & $\begin{array}{l}\text { Makanan yang saya pilih untuk dikonsumsi memudahkan saya mencapai kadar gula } \\
\text { darah normal }\end{array}$ & $6(17,1)$ & $26(74,3)$ & $2(5,7)$ & $1(2,9)$ & $2(66)$ \\
\hline 5 & Saya tidak banyak makan makanan manis atau makanan yang kaya karbohidrat * & $5(14,3)$ & $14(40)$ & $12(34,3)$ & $4(11,4)$ & $1,6(53)$ \\
\hline 9 & $\begin{array}{l}\text { Saya mematuhi anjuran makanan yang direkomendasikan dan yang tidak } \\
\text { direkomendasikan oleh dokter }\end{array}$ & $1(2,9)$ & $24(68,6)$ & $6(17,1)$ & $4(11,4)$ & $1,6(53)$ \\
\hline 13 & Saya tidak makan dalam porsi besar dan berlebihan * & $5(14,3)$ & $18(51,4)$ & $11(31,4)$ & $1(2,9)$ & $1,7(56)$ \\
\hline 17 & $\begin{array}{l}\text { Saya memperkirakan kandungan karbohidrat dari makanan saya (untuk mencapai kadar } \\
\text { glukosa yang lebih baik dan terkontrol). }\end{array}$ & $8(22,8)$ & $21(60)$ & $5(14,3)$ & $1(2,9)$ & $2(66)$ \\
\hline 18 & Saya makan dengan memperhatikan kondisi diabetes saya * & $12(34,3)$ & $13(37,2)$ & $6(17,1)$ & $4(11,4)$ & $1,9(63)$ \\
\hline \multicolumn{6}{|c|}{ Skor Rata-Rata Domain Kontrol Diet } & $0,6(60)$ \\
\hline \multicolumn{7}{|c|}{ Domain Manajemen Glukosa } \\
\hline 1 & Saya memeriksa kadar gula darah saya secara teliti dan hati-hati & $11(31,4)$ & $23(65,7)$ & $0(0)$ & $1(2,9)$ & $2,3(76)$ \\
\hline 4 & Saya menggunakan obat diabetes saya sesuai resep / yang disetujui. & $11(31,4)$ & $21(60)$ & $2(5,7)$ & $1(2,9)$ & $2,2(73)$ \\
\hline 6 & $\begin{array}{l}\text { Saya menyimpan catatan nilai gula darah untuk mengelola diabetes saya supaya lebih } \\
\text { baik. }\end{array}$ & $11(31,4)$ & $20(57,2)$ & $4(11,4)$ & $0(0)$ & $2,2(73)$ \\
\hline 10 & $\begin{array}{l}\text { Saya cukup sering memeriksa kadar gula darah saya yang bertujuan untuk mencapai } \\
\text { kadar glukosa yang baik* }\end{array}$ & $12(34,3)$ & $15(42,9)$ & $6(17,1)$ & $2(5,7)$ & $2,1(68)$ \\
\hline 12 & Saya tidak melewatkan pengobatan diabetes saya (mis. Insulin, tablet) ${ }^{*}$ & $11(31,4)$ & $13(37,2)$ & $11(31,4)$ & $0(0)$ & $2(66)$ \\
\hline
\end{tabular}


Tabel 6. Frekuensi Manajemen Diri Responden Per Item (lanjutan)

\begin{tabular}{|c|c|c|c|c|c|c|}
\hline \multicolumn{7}{|c|}{ Domain Aktivitas Fisik } \\
\hline 8 & Saya melakukan latihan fisik secara teratur untuk mencapai kadar gula darah normal & $8(22,8)$ & $19(54,3)$ & $5(14,3)$ & $3(8,6)$ & $1,9(63)$ \\
\hline 11 & $\begin{array}{l}\text { Saya melakukan aktivitas fisik seperti olahraga, karena hal tersebut baik untuk diabetes } \\
\text { saya / kesehatan saya * }\end{array}$ & $10(28,6)$ & $16(45,7)$ & $9(25,7)$ & $0(0)$ & $2(66)$ \\
\hline 15 & Saya aktif secara fisik terkait penyakit diabetes saya / kesehatan saya * & $15(42,9)$ & $8(22,8)$ & $11(31,4)$ & $1(2,9)$ & $2,1(70)$ \\
\hline \multicolumn{5}{|c|}{ Skor Rata-Rata Domain Aktivitas Fisik } & \multicolumn{2}{|l|}{$0,66(66)$} \\
\hline \multicolumn{7}{|c|}{ Domain Kontrol Dokter dan Domain Perawatan Diri } \\
\hline \multicolumn{7}{|c|}{3} \\
\hline & \multicolumn{5}{|l|}{ 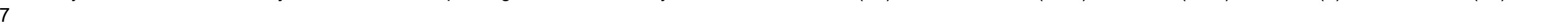 } & $2(66)$ \\
\hline \multicolumn{6}{|c|}{ ( } & $2,3(76)$ \\
\hline & Berkenaan dengan diabetes saya, saya harus lebih sering mengunjungi dokter. & $14(40)$ & $15(42,9)$ & $6(17,1)$ & $0(0)$ & $2,2(73)$ \\
\hline 19 & $\begin{array}{l}\text { Saya memeriksa / mendiskusikan perawatan diabetes saya dengan dokter secara } \\
\text { teratur. }\end{array}$ & $11(31,4)$ & $21(60)$ & $3(8,6)$ & $0(0)$ & $2,2(73)$ \\
\hline 16 & Saya dapat meningkatkan perawatan diri terhadap diabetes saya secara signifikan. & $20(57,1)$ & $6(17,1)$ & $3(8,6)$ & $6(17,1)$ & $2,1(70)$ \\
\hline 20 & Tingkat perawatan diri terhadap diabetes yang saya derita adalah tidak buruk * & $13(37,2)$ & $18(51,4)$ & $4(11,4)$ & $0(0)$ & $2,2(73)$ \\
\hline \multicolumn{6}{|c|}{ Skor Rata-Rata Domain Kontrol Dokter dan Domain Perawatan Diri } & $0,72(72)$ \\
\hline \multicolumn{6}{|c|}{ Skor Total Rata-rata Seluruh Responden } & $0,67(67,6)$ \\
\hline
\end{tabular}

Keterangan:

* Pernyataan unfavorable yang diubah menjadi pernyataan favorable

*Sangat setuju $=$ skor 3 , Setuju $=$ skor 2, Ragu-ragu $=$ skor 1 , Tidak Setuju $=$ skor 0.

* Skor Maksimal $=60$ 
Data hasil penelitian menunjukan bahwa $50 \%$ pasien masih menjawab salah pada item nomor 5 terkait makanan yang harus dihindari oleh pasien diabetes. Menurut Wijayakusuma (2009) pasien diabetes mellitus perlu menghindari makanan manis, hal ini dilakukan untuk mencegah terjadinya komplikasi yang dapat merusak saraf atau merusak pembuluh darah yang dapat meningkatkan risiko terjadinya serangan jantung, stroke, gagal ginjal, serta komplikasi lain. Sehingga perlu dilakukan edukasi terkait diet pada pasien diabetes mellitus. Diet yang dianjurkan adalah makanan dengan komposisi yang seimbang dalam hal karbohidrat (6070\%), protein (10-15\%) dan lemak (20-25\%), sesuai dengan angka kecukupan gizi. Selain itu, jumlah kalori perlu disesuaikan dengan pertumbuhan, status gizi, umur, stress akut dan kegiatan fisik, yang pada dasarnya ditujukan untuk mencapai dan mempertahankan berat badan ideal (Dewi, 2013).

Dari 35 responden, pasien yang menjawab sangat setuju sebanyak 32\% dan setuju 52,6\% pada domain manajemen glukosa. Hasil penelitian menyatakan bahwa sebagian besar responden menyadari pentingnya kadar glukosa darah dengan cara tidak melewatkan waktu pengobatan, selalu melakukan cek rutin kadar gula darah, mengkonsumsi obat yang sudah didapatkan dari dokter dan selalu mengelola kadar gula darah dengan menyimpan catatan nilai gula darah dari setiap kali pemeriksaan. Meskipun 47\% pasien masih memiliki tingkat manajemen yang kurang baik terkiat dengan waktu pemeriksaan kadar glukosa darah. Pemantauan kadar gula darah secara berkala perlu dilakukan untuk mengevaluasi keberhasilan kontrol glikemik. Menurut Kristiana (2012), pemantauan kadar gula darah penderita diabetes mellitus secara teratur merupakan bagian yang penting dari pengendalian penyakit diabetes mellitus, pemeriksaan kadar gula darah yang teratur dan terus menerus dapat mencegah meningkatnya kadar gula darah secara drastis, yang dapat membantu menentukan penanganan yang tepat sehingga mengurangi resiko komplikasi yang beratn dan dapat meningkatkan kualitas hidup penderita diabetes mellitus.

Kuesioner DSMQ juga memiliki pernyataan terkait dengan aktivitas fisik. Dari hasil penelitian didaptkan bahwa $31,4 \%$ pasien menjawab sangat setuju dan $41 \%$ pasien menjawab setuju terkait dengan aktivitas fisik. Latihan fisik merupakan salah satu pilar dalam pengelolaan diabetes mellitus yang berfungsi untuk memperbaiki sensitivitas insulin dan juga untuk menjaga kebugaran tubuh, latihan fisik bisa membantu memasukan glukosa kedalam sel tanpa membutuhkan insulin, selain itu latihan fisik juga bisa untuk menurunkan berat badan diabetisi yang obesitas serta mencegah laju progresivitas gangguan toleransi glukosa menjadi diabetes mellitus.

Menurut Barnes (2011) aktivitas fisik secara langsung berhubungan dengan kecepatan pemulihan gula darah otot, saat aktivitas fisik, otot menggunakan glukosa yang disimpannya sehingga glukosa yang tersimpan akan berkurang yang mana hal tersebut dapat meningkatkan kontrol gula darah. Pernyataan tersebut tertuang pada item nomor 8, 11 dan 15. Hasil menyatakan bahwa item yang memiliki persentase terendah yaitu item 8 terkait pelaksanaan aktivitas fisik secara teratur. Manfaat besar dari aktivitas fisik atau berolahraga pada diabetes melitus antara lain menurunkan kadar glukosa darah, mencegah kegemukan, ikut berperan dalam mengurangi terjadinya komplikasi, gangguan lipid darah dan peningkatan tekanan darah (Ilyas, 2007). 
Terkait dengan kontak dokter dan perawatan diri hasil didapatkan bahwa $30 \%$ pasien menjawab sangat setuju dan $53,5 \%$ pasien menjawab setuju pada domain tersebut. Sebanyak $66 \%$ pasien memliki manajemen yang baik terkait kontak dokter dan perawatan diri. Pengelolaan diabetes mellitus memerlukan penanganan dan pengelolaan secara teratur yang mencakup terapi non-obat dan terapi obat. Menurut Anani et al, (2012) penyakit diabetes mellitus memerlukan perawatan medis dan penyuluhan untuk self-management yang berkesinambungan yang bertujuan untuk mencegah komplikasi akut maupun kronis, penatalaksanaan diabetes ditujukan untuk pengendalian faktor metabolik dan faktor risiko kardiovaskuler. Hasil penelitian didapatkan bahwa pasien rata rata menjawab pernyataan 16 mengenai perawatan diri sebanyak 40\%. diabetes mellitus tipe 2 merupakan penyakit kronik yang tidak dapat disembuhkan tetapi sangat potensial untuk dapat dicegah dan dikendalikan melalui 4 pilar pengelolaan diabetes mellitus yang meliputi edukasi, diet, olahraga dan terapi pengobatan. Karena diabetes mellitus adalah penyakit yang berhubungan dengan gaya hidup, maka berhasil tidaknya pengelolaan diabetes mellitus sangat tergantung dari pasien itu sendiri dalam mengubah perilakunya, secara teori, proses perubahan perilaku melalui 3 tahap yaitu pengetahuan, sikap dan praktik (Notoatmodjo, 2011).

Tabel 7. Frekuensi Tingkat Manajemen Diri Responden

\begin{tabular}{lcc}
\hline $\begin{array}{c}\text { Kategori Tingkat } \\
\text { Manajemen diri }\end{array}$ & $\begin{array}{c}\text { Jumlah } \\
\text { Responden }\end{array}$ & Presentase (\%) \\
\hline Baik $(56-100)$ & 23 & 65,7 \\
Kurang baik $(<56)$ & 12 & 34,3 \\
\hline Total & $\mathbf{3 5}$ & $\mathbf{1 0 0}$ \\
\hline
\end{tabular}

Berdasarkan hasil penelitian pasien prolanis diabetes mellitus di Puskesmas I Purwokerto Timur menunjukkan bahwa 65,7\% responden memiliki tingkat manajemen diri yang baik. Pasien yang memiliki kategori manajemen diri baik lebih banyak terdapat pada perempuan (63\%).

\section{Hubungan Tingkat Pengetahuan Pasien Terhadap Manajemen Diri}

Uji normalitas dilakukan terlebih dahulu terhadap data yang sudah didapatkan dengan menggunakan software SPSS, untuk mengetahui data terdistribusi normal atau tidak. Uji yang digunakan yaitu uji Shapiro wilk dikarenakan jumlah sampel $\leq 50$. Jika nilai $p>\alpha=0,05$ maka data terdistribusi normal dan jika nilai $p<\alpha=0,05$ maka data tidak terdistribusi normal (Priyatno, 2010). Hasil uji normalitas didapatkan nilai $p=0,249(p>0,05)$ untuk pengetahuan dan $p=0,67(p>0,05)$ untuk manajemen diri. Sehingga dapat disimpulkan bahwa data tingkat pengetahuan dan manajemen diri terdistribusi normal.

Analisis uji korelasi mendapatkan hasil bahwa terdapat hubungan antara pengetahuan terhadap manajemen diri dengan nilai $p=0,001 \quad(p \leq 0,05)$ dengan nilai korelasi 0,74 , hasil tersebut menyatakan bahwa pengetahuan dan manajemen diri berkorelasi kuat dengan arah hubungan yang positif. Dari hasil di atas dapat disimpulkan bahwa semakin rendah tingkat pengetahuan seseorang maka manajemen diri responden akan semakin rendah. Pengetahuan sangat diperlukan untuk mengendalikan dan mengurangi dampak yang disebabkan oleh diabetes mellitus (Chen, et al., 2015). Selfmanagement bermanfaat untuk mengembangkan keterampilan yang dihadapi oleh pasien untuk meningkatkan keyakinan diri (self-efficacy) (Zainudin, et al, 2018). Keterampilan dan pengetahuan dapat menentukan pengelolaan 
yang terbaik untuk pasien (Handayani et al, 2013).

Tabel. 8 Hasil Uji Pearson Correlation Antara Tingkat Pengetahuan Terhadap Manajemen Diri Pasien Diabetes Mellitus Tipe 2

\begin{tabular}{|c|c|c|c|c|c|c|}
\hline \multirow{2}{*}{$\begin{array}{l}\text { Tingkat } \\
\text { Pengeta } \\
\text { huan }\end{array}$} & \multicolumn{2}{|c|}{$\begin{array}{c}\text { Tingkat Manajemen } \\
\text { Diri }\end{array}$} & \multirow{2}{*}{$\begin{array}{c}\text { Tingkat } \\
\text { Manajamen } \\
\text { Diri } \bar{x}(\%)\end{array}$} & \multirow[t]{2}{*}{$r$} & \multirow[t]{2}{*}{$P$} & \multirow{2}{*}{ Keterangan } \\
\hline & Baik & $\begin{array}{c}\text { Kurang } \\
\text { Baik }\end{array}$ & & & & \\
\hline Rendah & 1 & 1 & $61,67 \%$ & & & $\begin{array}{c}\text { Terdapat } \\
\text { hubungan }\end{array}$ \\
\hline Sedang & 14 & 11 & $61,27 \%$ & 0,74 & 0,001 & $\begin{array}{c}\text { antara } \\
\text { pengetahuan }\end{array}$ \\
\hline Tinggi & 8 & 0 & $78,3 \%$ & & & $\begin{array}{c}\text { terhadap } \\
\text { manajemen } \\
\text { diri }\end{array}$ \\
\hline
\end{tabular}

\section{SIMPULAN}

Berdasarkan hasil penelitian yang telah dilakukan, maka dapat disimpulkan bahwa:

1. Pasien diabetes mellitus tipe 2 di Puskesmas 1 Purwokerto Timur memiliki tingkat pengetahuan sebesar 13,86, dimana skor tersebut termasuk skor dengan kategori pengetahuan sedang.

2. Pasien diabetes mellitus tipe 2 di Puskesmas 1 Purwokerto Timur memiliki manajemen diri $67,6 \%$, dimana skor tersebut termasuk skor dengan kategori tingkat manajemen diri baik.

3. Terdapat hubungan antara pengetahuan terhadap manajemen diri $p=0,000$ dengan nilai $r=0,838$ pada pasien prolanis diabetes mellitus tipe 2 di Puskesmas I Purwokerto Timur.

\section{REFERENSI}

Anani, S., Ari, U., Praba, G., 2012, Hubungan Antara Perilaku Pengendalian Diabetes dan Kadar Glukosa Darah Pasien Rawat Jalan Diabetes Melitus (Studi Kasus di RSUD Arjawinangun Kabupaten Cirebon, Jurnal Kesehatan Masyarakat, 1(2): 466 - 478.

Ariani, Y., 2011, Hubungan antara Motivasi dengan Efikasi Diri Pasien Diabetes Mellitus Tipe 2 dalam Konteks Asuhan Keperawatan di RSUP H. Adam Malik Medan, Tesis, Universitas Indonesia.

Arisman, 2011, Buku Ajar Ilmu Gizi Obesitas, Diabetes Mellitus dan Dislipidemia, EGC, Jakarta, 44-54.

Aweko, J., De Man, J., Absetz, P., Ostenson, C.G., Swartling Peterson, S., Molsted Alvesson, H., Daivadanam, M., 2018, Patient And Provider Dilemmas Of Type 2 Diabetes SelfManagement: A Qualitative Study In Socioeconomically Disadvantaged Communi-Ties In Stockholm, International Journal of Environmental Research and Public Health, 15 (9).

Barnes, D.E., 2011, Program Olahraga Diabetes, Citra Aji Parama, Yogyakarta.

BPJS 2014, Peraturan Badan Penyelenggara Jaminan Sosial Kesehatan Nomor 1 Tahun 2014 Tentang Penyelenggaraan Jaminan Kesehatan, Badan Penyelenggara Jaminan Sosial, Jakarta.

Chen, L., Pei, J.H., Kuang, J., Chen, H.M., Chen, Z., Li, Z.W., Yang, H.Z., 2015, Effect Of Lifestyle Intervention In Patients With Type 2 Diabetes: A Meta-Analysis, Metabolism, 64(2):338-347.

Dahlan, M.S., 2011, Statistik untuk Kedokteran: Deskriptif, Bivariat, dan Multivariat Dilengkapi Aplikasi dengan Menggunakan SPSS Edisi 5, Salemba Medika, Jakarta.

Dewi, 2013, Menu Sehat 30 Hari untuk Mencegah dan Mengatasi Diabetes, Media Pustaka, Jakarta.

Dhamayanti, F.A., 2018, Hubungan Manajemen Diri Diabetes Dengan Kontrol Gula Darah Pasien Diabetes Melitus Tipe 2 Pada Peserta Prolanis Di Bandar Lampung, Skripsi, Pada Program Studi Pendidikan Dokter Fakultas Kedokteran Universtas Lampung.

DINKES, 2017, Profil Kesehatan Kabupaten Banyumas Tahun 2017, Kepala Dinas Kesehatan 
Kabupaten Banyumas, Purwokerto.

DINKES, 2017, Profil Kesehatan Provinsi Jawa Tengah 2017, Kepala Dinas Kesehatan Jawa Tengah, Semarang.

Emilia, E. A., 2015, Hubungan Dukungan Sosial dan Perilaku Perawatan Diri Penyandang Diabetes Melitus Tipe 2, Jurnal Informasi Kesehatan, 14(2).

Garcia, A., Evangelina, T., Villagomez, M., Sharo, A., Brown, P., Kamiar, K., \& Hanis, P, 2001, The Star Country Diabetes Education Study: Development of the SpanishLanguange Diabetes Knowledge Questionnaire, Diabetes Care, 24 (1).

Gharaibeh, B., Tawalbeh, L.I., 2018, Diabetes self-care management practices among insulintaking patients, Journal of Research in Nursing, 23 (7), 553-565.

Harista, RA, Lisiswanti, R, 2015. Depresi Pada penderita Diabetes Tipe 2. Jurnal Majority Unila, Vol 4 No 9.73-77

Hasdiana, 2012, Mengenal Diabetes Melitus Pada Orang Dewasa dan Anak-anak dengan Solusi Herbal, Nuha Medika, Yogyakarta.

Hikmah, D.K.N., 2015, Pengaruh Senam Diabetes Melitus Terhadap Status Kardiovaskuler Pasien Diabetes Melitus Tipe 2 Di Desa Rambipuji Kecamatan Rambipuji Kabupaten Jember

Ilyas, E., 2007, Penatalaksanaan diabetes melitus terpadu, Balai Penerbit Fakultas Kedokteran Universitas Indonesia, Jakarta.

Irnawati, K., Nursam, M., 2014, Pengaruh Diabetes Self- Management Education Terhadap Self Care Behavior pada pasien Diabetes Mellitus, STIKES Wira Medika PPNI, Bali

Kemenkes RI, 2013, Riset Kesehatan Dasar; RISKESDAS, Balitbang Kemenkes RI, Jakarta.

Kugbey, N., Kwaku, O.A., \& Korkor, A. 2017. Illness Perception, Diabetes Knowledge and Self-Care Practices Among Type-2 Diabetes Patients: A Cross-Sectional Study, Biomed central, 10(381).

Kueh, Y.C., Tony,M., Erika, B., dan Himanshu, S. 2015, Modelling Of Diabetes Knowledge, Attitudes, Self-Management, And Quality Of Life: A Cross-Sectional Study With An Australian Sample, BioMed Central, 13 (129).

Le., C, Jun, D., ShuZhankun, Lu, Y., Jie, T.., 2011, Socioeconomic Differences In Diabetes Prevalence, Awareness, and Treatment In Rural Southwest China, Tropical Medicine and International Health, 16(9):1070-1076.

Maryunani, Anik, 2013, Perawatan Luka Modern Praktis Pada Wanita dengan Luka Diabetes, Trans Info Media, Jakarta.

Notoatmodjo, S., 2011, Ilmu Perilaku Kesehatan, Rineka Cipta, Jakarta

Pangemanan. D., Mayulu. N., 2014, Analisis Faktor Resiko Penyebab Terjadinya Diabetes Melitus Tipe 2 Pada Wanita Usia Produktif di Puskesmas Wawonasa, Jurnal eBiomedik.

Perdana, A.A., Burhannudin I., Devi, U.R., 2013, Hubungan Tingkat Pengetahuan Tentang Penyakit Diabetes mellitus Dengan Pengendalian Kadar Glukosa Darah Pada Pasien Diabetes mellitus Tipe II Di Rsu Pku Muhammadiyah Surakarta, Biomedika, 5(2).

PERKENI, 2015, Pengelolaan Dan Pencegahan Diabetes Mellitus Tipe 2 Di Indonesia, PB PERKENI, Jakarta.

Putri, N. H. K., Isfandiari, M.A., 2013, Hubungan Empat Pilar Pengendalian Diabetes Mellitus Tipe 2 Dengan Rerata Kadar Gula Darah, Departemen Epidemiologi FKM Universitas Airlangga, Surabaya, 1(2):234-243.

Restada, J., R., 2016, Hubungan Lama Menderita Dan Komplikasi Diabetes Melitus Dengan Kualitas Hidup Pada Penderita Diabetes Melitus Di Wilayah Puskesmas Gatak Sukoharjo, Skripsi, Universitas Muhammadiyah Surakarta.

Riskesdas, 2013, Badan Penelitian dan Pengembangan Kesehatan Kementerian RI tahun 2013, Balitbang Kemenkes RI, Jakarta.

Riyambodo, B., Purwanti, O.S., 2017, Hubungan antara tingkat pengetahuan dengan tingkat distres pada pasien diabetes melitus di RSUD Dr. Moewardi Surakarta, Skripsi, Universitas Muhammadiyah Surakarta.

Sari, N., Hisyam, B., 2014. Hubungan Antara Diabetes Mellitus Tipe 2 dengan Kejadian Gagal Ginjal Kronik di Rumah Sakit PKU Muhammadiya Yogyakarta. JKKI Vol 6 No 1.

Sabi, F.A., Kusrini, A.T., Elly, L., 2019, Factors Supporting Self-Care Management On Diabetes Mellitus Type 2 Patients: A Literature Review, Journal Keperawatan UMM, Vol 10,no 1.

Saifunurmazah, D., 2013, Kepatuhan Penderita Diabetes Mellitus Dalam Menjalani Terapi Olahraga Dan Diet, Skripsi, Fakultas Ilmu Pendidikan, Universitas Negeri Semarang, Semarang.

Santosa, A., Puput, A.T., \& Endiyono, 2017, Hubungan Riwayat Garis Keturunan Dengan Usia Terdiagnosis Diabetes Melitus Tipe II, URECOL, ISSN 2407-9189.

Schmitt, A., Annika, G., Norbert, H., Bernhard, K., Jörg, H., dan Thomas, H., 2013, The Diabetes Self-Manajemen Questionnaire (DSMQ): Development and Evaluation of an Instrument to Assess Diabetes Self-Care Activities Associated With Glycaemic Control, BioMed Central. 11(138).

Schwinghammer, L.T. 2015, Pharmacotherapy Handbook, 9th Edition 'Chapter 19 Diabetes Mellitus', The Mc Graw Hill Company, USA, 1891-1939. 
Setyorini, A., 2017, Stres Dan Koping Pada Pasien Dengan Diabetes Mellitus Tipe 2 dalam Pelaksanaan Manajemen Diet di Wilayah Puskesmas Banguntapan II Kabupaten Bantul, Health Sciences and Pharmacy Journal, 1 (1):1-9.

Soegondo, 2011, Penatalaksanaan Diabetes Terpadu, Balai Penerbit FK UI, Jakarta.

Sugiyono, 2018, Metode Penelitian Pendidikan, Alfabeta, Bandung.

Sukandar, E.Y., Andrajati. R., Sigit. J., Adnyana, I,K., Setiadi, A.A.P., dan Kusnandar., 2013, Farmakoterapi, PT ISFI Penerbitan, Jakarta.

Sulistria, YM. 2013, Tingkat Self Care Pasien Rawat Jalan Diabetes Mellitus Tipe II di Puskesmas Kalirungkut Surabaya, Jurnal Ilmiah Mahasiswa, Universitas Surabaya,2(2).

Suyono, S., 2009, Buku Ajar Ilmu Penyakit Dalam. Jilid III. Interna Publishing, Jakarta.

Waspadji, S., 2011, Penatalaksanaan Diabetes Melitus Terpadu Bagi Dokter Maupun Edukator Diabetes, Fakultas Kedokteran Universitas Indonesia, Jakarta.

Wijayakusuma, H., 2009, Bebas Diabetes Mellitus Ala Hembing, Puspa Swara, Jakarta.

Yusra, A., 2011, Hubungan Antara Dukungan Keluarga dengan Kualitas Hidup Pasien Diabetes Melitus Tipe 2 di Poliklinik Penyakit Dalam Rumah Sakit Umum Pusat Fatmawati Jakarta, Tesis, Fakultas Ilmu Keperawatan Universitas Indonesia, Depok.

\section{UCAPAN TERIMA KASIH}

Ucapan terimakasih kami sampaikan kepada apt. Laksmi Maharani, M.Sc dan apt. Nia Kurnia Sholihat, M.Sc atas masukan dan arahan dalam proses penelitian ini.

\section{KONTRIBUSI PENULIS}

SRN berperan dalam membuat konsep dan pengumpulan data. HP berperan dalam interpretasi data dan menyusun naskah publikasi dan VVF berperan dalam interpretasi data. Semua penulis berkontribusi dalam merancang penelitian, interpretasi data dan menyetujui versi akhir naskah.

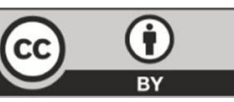
Commons Lisensi Internasional Attribution 4.0, yang memungkinkan penggunaan, berbagi, adaptasi, distribusi, dan reproduksi dalam media atau format apa pun, selama Anda memberikan kredit yang sesuai kepada penulis asli dan sumbernya, memberikan tautan ke lisensi Creative Commons, dan menerangkan jika perubahan telah dilakukan. Gambar atau materi pihak ketiga lainnya dalam artikel ini termasuk dalam lisensi Creative Commons artikel, kecuali dinyatakan sebaliknya dalam batas kredit untuk materi tersebut. Jika materi tidak termasuk dalam lisensi Creative Commons artikel dan penggunaan yang Anda maksudkan tidak diizinkan oleh peraturan perundang-undangan atau melebihi penggunaan yang diizinkan, Anda harus mendapatkan izin langsung dari pemegang hak cipta. Untuk melihat salinan lisensi ini, kunjungi https://creativecommons.org/licenses/by/4.0/deed.id. 